NASZA DERMATOLOGIA Onlin OUR DERMATOLOGY Online

Source of Support:

Nil

Competing Interests:

None

\section{EPONYMS IN THE DERMATOLOGY LITERATURE LINKED TO UNITED KINGDOM}

\author{
Khalid Al Aboud ${ }^{1}$, Ahmad Al Aboud ${ }^{2}$ \\ ${ }^{1}$ Department of Public Health, King Faisal Hospital, Makkah, Saudi Arabia \\ ${ }^{2}$ Dermatology Department, King Abdullah Medical City, Makkah, Saudi Arabia
}

Corresponding author: Dr. Khalid Al Aboud

amoa65@hotmail.com
The United Kingdom of Great Britain and Northern Ireland, commonly known as the United Kingdom (UK) and Britain, is a sovereign state located off the north-western coast of continental Europe.

The United Kingdom is a developed country and remains a great power with considerable economic, cultural, military, scientific and political influence internationally [1].

England and Scotland were leading centres of the Scientific
Revolution from the 17th century and the United Kingdom led the Industrial Revolution from the 18th century, and has continued to produce scientists and engineers credited with important advances [1].

There are several eponyms in dermatology literature, which are linked to United Kingdom.

In Table I [2-14], we highlighted on some examples of eponyms in dermatology literature, linked to United Kingdom.

\begin{tabular}{|c|l|}
\hline $\begin{array}{c}\text { Eponyms in the dermatology } \\
\text { literature linked to United } \\
\text { Kingdom }\end{array}$ & \multicolumn{1}{|c|}{ Remarks } \\
\hline $\begin{array}{c}\text { Anderson-Fabry disease [2] } \\
\text { [3] }\end{array}$ & $\begin{array}{l}\text { Also known as Fabry disease, angiokeratoma corporis diffusum and alpha- } \\
\text { galactosidase A deficiency;is a rare X-linked lysosomal storage disease, which can cause a wide } \\
\text { range of systemic symptoms. The disease is named for Johannes Fabry (1860-1930), who was } \\
\text { a German dermatologist. And William Anderson (1842-1900), (Fig. 1), who was an English } \\
\text { surgeon and dermatologist. }\end{array}$ \\
\hline Brooke-Spiegler syndrome (BSS) & $\begin{array}{l}\text { Brooke-Spiegler syndrome (BSS), multiple familial trichoepithelioma (MFT), which also is } \\
\text { known as epithelioma adenoides cysticum or Brooke's disease, and familial cylindromatosis are } \\
\text { allelic, dominantly-inherited conditions with overlapping clinical features. All are characterized } \\
\text { by the appearance of benign, adnexal neoplasms in late childhood and early adolescence.Tumors } \\
\text { commonly occuring in BSS include spiradenomas, trichoepitheliomas and cylindromas.BSS is } \\
\text { named for, Henry Ambrose Grundy Brooke (1854-1919), who was, an English dermatologist. } \\
\text { Eduard Spiegler (1860-1908), was and Austrian chemist and dermatologist. }\end{array}$ \\
\hline Donovan bodies [4,5] & $\begin{array}{l}\text { Donovan bodies are rod-shaped, oval organisms that can be seen in the cytoplasm of } \\
\text { mononuclear phagocytes or histiocytes in tissue samples from patients with granuloma inguinale. } \\
\text { They were discovered by Charles Donovan (1863-1951). In 1905 he identified the micro-organism } \\
\text { responsible for the disease granuloma inguinale. This also bears his name Donovania } \\
\text { granulomatosis. } \\
\text { Donovan was born in Calcutta. At the age of thirteen he was sent to Cork City to live with his } \\
\text { grandfather to advance his secondary and university education. }\end{array}$ \\
\hline Table I. Selected Eponyms in the
\end{tabular}




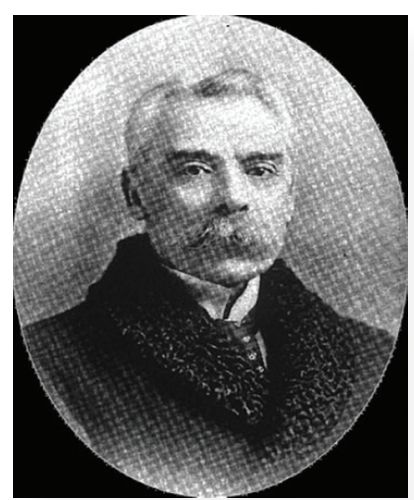

Figure 1. William Anderson (1842-1900)
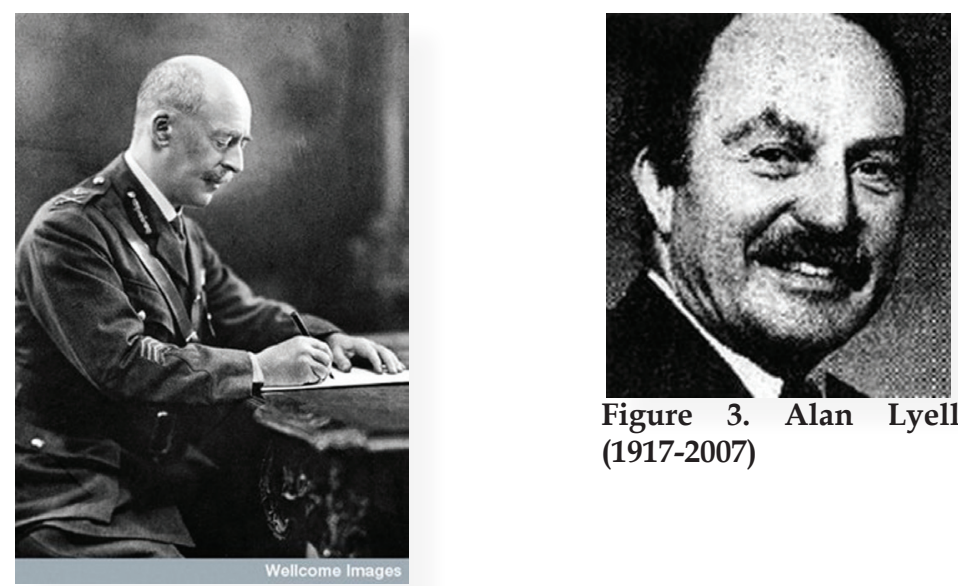

Figure 3. Alan Lyell (1917-2007)

Figure 2. William Boog Leishman

FRS (1865-1926)

\begin{tabular}{|c|c|}
\hline $\begin{array}{l}\text { Eponyms in the dermatology } \\
\text { literature linked to United } \\
\text { Kingdom }\end{array}$ & Remarks \\
\hline Dowling-Degos disease [6] & $\begin{array}{l}\text { Also known as, reticulate pigmented anomaly of flexures, is a rare genetic disease of the skin, } \\
\text { clinically characterized by flexural brown pigmented reticulate macules, comedo-like papules } \\
\text { on the back, neck and pitted perioral or facial scars. Reticulated hyperpigmentation anomalies } \\
\text { were initially distinguished from acanthosis nigricans by Dowling and Freudenthal in 1938. In } \\
1954 \text {, Degos and Ossipowski described a patient with a similar case. The syndrome designated } \\
\text { Dowling-Degos Disease (DDD) by Wilson-Jones and Grice in 1978. Dowling was an English } \\
\text { physician. }\end{array}$ \\
\hline Hartnup disease [7] & $\begin{array}{l}\text { It is inborn error of tryptophan excretion. Also known as ,pellagra-like dermatosis”. It is an } \\
\text { autosomal recessive metabolic disorder affecting the absorption of nonpolar amino acids The } \\
\text { disease was named for the Hartnup family of England, who were looked at in a } 1956 \text { study of } \\
\text { the disease. }\end{array}$ \\
\hline Leishmaniasis $[4,5]$ & $\begin{array}{l}\text { Leishmaniasis is a zoonotic infection caused by protozoa that belong to the genus Leishmania. } \\
\text { The disease is named after Leishman, who first described it in London in May } 1903 \text {. } \\
\text { Lieutenant-General Sir William Boog Leishman (1865-1926), (Fig. 2), was a Scottish } \\
\text { pathologist and British Army medical officer. In 1901, while examining pathologic specimens } \\
\text { of a spleen from a patient who had died of kala azar he observed oval bodies and published his } \\
\text { account of them in 1903. } \\
\text { Captain Charles Donovan confirmed the finding of what became known as Leishman-Donovan } \\
\text { bodies in smears taken from patients in Madras in southern India. }\end{array}$ \\
\hline Lyell's syndrome [8] & $\begin{array}{l}\text { This is another name for toxic epidermal necrolysis Toxicepidermal necrolysis. It is named after, } \\
\text { Alan Lyell (1917-2007), (Fig. 3). }\end{array}$ \\
\hline Rowell syndrome [9] & $\begin{array}{l}\text { This syndrome is a combination of erythema multiforme-like lesions in patients with, lupus } \\
\text { erythematosus. Some authors believe that, the coexistence of cutaneous lupus erythematosus and } \\
\text { erythema multiform does not justify the framing of a separate syndrome as suggested by Rowell } \\
\text { et al, in } 1963 \text {. }\end{array}$ \\
\hline $\begin{array}{r}\text { Sneddon-Wilkinson } \\
{[10,11]}\end{array}$ & $\begin{array}{l}\text { This is another name for subcorneal pustular dermatosis. It was first described by Sneddon and } \\
\text { Wilkinson in 1956. It is a rare, benign, chronic, sterile pustular eruption which usually develops } \\
\text { in middle-age or elderly women; it is rarely seen in childhood and adolescence. The etiology of } \\
\text { this entity is unknown. The syndrome is named after } 2 \text { British dermatologists, Ian Bruce Sneddon } \\
\text { (1915-1987), (Fig. 4), and Daryl Sheldon Wilkinson. }\end{array}$ \\
\hline
\end{tabular}




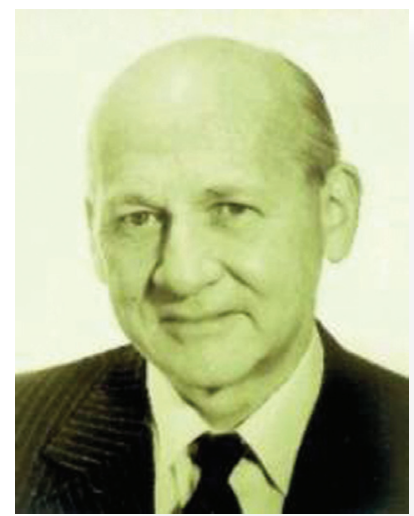

Figure 4. Ian Bruce Sneddon (1915-1987)

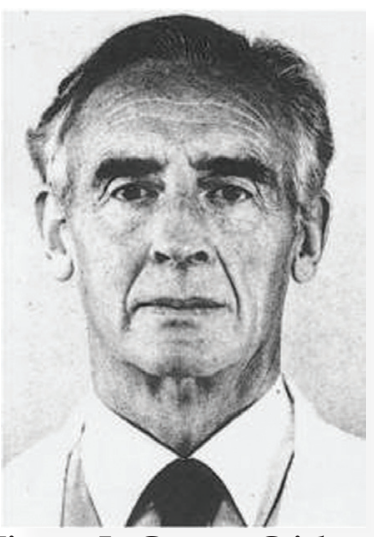

Figure 5. George Crichton Wells (1914-1999)

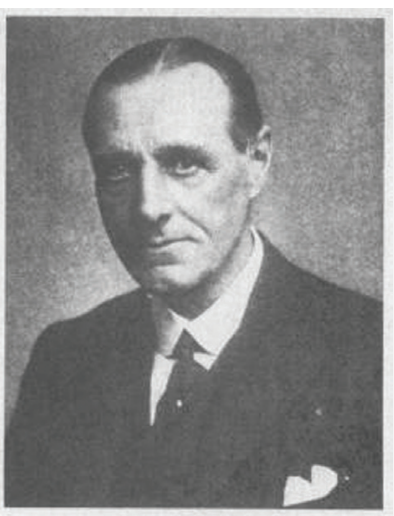

Figure 6. Arthur Whitfield (1868-1947)

\begin{tabular}{|c|l|}
\hline $\begin{array}{c}\text { Eponyms in the dermatology } \\
\text { literature linked to United } \\
\text { Kingdom }\end{array}$ & \multicolumn{1}{c|}{ Remarks } \\
\hline Sweet syndrome [12] & $\begin{array}{l}\text { Also known as, acute febrile neutrophilic dermatosis. It was first described in 1964 by Dr. Robert } \\
\text { Douglas Sweet (1917-2001), who was an English physician. It was also known as Gomm-Button } \\
\text { disease in honour of the first two patients Dr. Sweet diagnosed with the condition. }\end{array}$ \\
\hline Wells Syndrome [13] & $\begin{array}{l}\text { This is another name for eosinophilic cellulites. Named after George Crichton Wells (1914- } \\
\text { 1999), (Fig. 5). }\end{array}$ \\
\hline Whitfield's ointment [14] & $\begin{array}{l}\text { Whitfield's Ointment is salicylic acid and benzoic acid in a suitable base, such as lanolin or } \\
\text { vaseline. It is used for the treatment of fungal infections.Named for, Arthur Whitfield (1868- } \\
\text { 1947), (Fig. 6), who was a British dermatologist. }\end{array}$ \\
\hline
\end{tabular}

Table I. Selected Eponyms in the dermatology literature linked to United Kingdom

\section{REFERENCES}

1. United Kingdom. Wikipedia ${ }^{\circledR}$ [Internet]. Wikimedia Foundation. [Updated 6 May 2013; cited 6 May 2013]. Available from: http:// en.wikipedia.org/wiki/United_Kingdom

2. Al Aboud K, Al Aboud D: Eponyms in the dermatology literature linked to Germany. Our Dermatol Online. 2013;4(Suppl. 2):429-32.

3. Trufant J, Robinson M, Patel R: Brooke-Spiegler syndrome. Dermatol Online J. 2012;18:16.

4. Bailey H, Bishop WJ: Leishman-Donovan bodies and donovaniasis; Sir William Boog Leishman, 1865-1926; Charles Donovan, 18631951. Br J Vener Dis. 1959;35:8-9.

5. Khorvash F, Naeini AE, Behjati M, Abdi F: Visceral leishmaniasis in a patient with cutaneous lesions, negative Leishman-Donovan bodies and immunological test: A case report. J Res Med Sci. 2011;16:1507-10

6. Zimmermann CC, Sforza D, Macedo PM, Azulay-Abulafia L, Alves Mde F, Carneiro SC: Dowling-Degos disease: classic clinical and histopathological presentation. An Bras Dermatol. 2011;86:97982.
7. Orbak Z, Ertekin V, Selimoglu A, Yilmaz N, Tan H, Konak M: Hartnup disease masked by kwashiorkor. J Health Popul Nutr. 2010;28:413-5.

8. Holubar K: [In Memoriam: Alan Lyell 1917-2007]. J Dtsch Dermatol Ges. 2008;6:421-2.

9. Antiga E, Caproni M, Bonciani D, Bonciolini V, Fabbri P: The last word on the so-called ,Rowell's syndrome'? Lupus. 2012;21:577-85. 10. Black MM: Obituary: Darrell Sheldon Wilkinson, MD, FRCP, FRSM. Br J Dermatol. 2010;162:231-3.

11. Scalvenzi M, Palmisano F, Annunziata MC, Mezza E, Cozzolino I, Costa C: Subcorneal pustular dermatosis in childhood: a case report and review of the literature. Case Rep Dermatol Med. 2013;2013:424797.

12. Anzalone CL, Cohen PR: Acute febrile neutrophilic dermatosis (Sweet's syndrome). Curr Opin Hematol. 2013;20:26-35.

13. Steffen C: The man behind the eponym. George Crichton Wells: eosinophilic cellulitis (Wells syndrome). Am J Dermatopathol. 2002;24:164-5.

14. Williams DI: Three British dermatologists. Arthur Whitfield, Erasmus Wilson, and Henry Radcliffe Crocker. Arch Dermatol. 1976;112:1654-8.

Copyright by Khalid Al Aboud, et al. This is an open access article distributed under the terms of the Creative Commons Attribution License, which permits unrestricted use, distribution, and reproduction in any medium, provided the original author and source are credited. 